\title{
Generalized Thyroid Hormone Resistance
}

National Cancer Institute

\section{Source}

National Cancer Institute. Generalized Thyroid Hormone Resistance. NCI Thesaurus.

Code C131816.

Decreased response to thyroid hormones in peripheral tissues and in the pituitary gland. 